\title{
Predicting Factors of Sexual Identity among Adolescent Girls in Jakarta
}

\author{
Diah Miranti Dewi ${ }^{1}$, Risatianti Kolopaking ${ }^{1}$ \\ ${ }^{1}$ Faculty of Psychology, Syarif Hidayatullah State Islamic University, Jakarta, Indonesia \\ *E-mail: diahmiranti@gmail.com
}

\begin{abstract}
The study aimed to assess peer acceptance, parent-adolescent communication, and religious orientation as predictors of sexual identity among adolescent girls in Jakarta. Participants were adolescent girls of 14 to 17 years $(n=240)$. Sexual identity was measured using De Cecco-Shively Social Sex-Role Inventory (DSI) Scale (Shively, Rudolph, \& Cecco, 1978). Peer acceptance was measured using Peer Acceptance Scale (Newcomb, Bukowski, \& Patte, 1993). Parent-adolescent communication was assessed using The Communication Parent-Adolescent Communication Scale (Barnes \& Olson, 1985). Religious orientation was assessed using Age-Universal Scale (Gorsuch \& Venable, 1983). Multiple regression analysis was used to assess whether peer acceptance, parent communication, and religious orientation significantly predicted adolescents girls sexual identity. The result showed that peer acceptance, parent communication, and religious orientation explained $18.1 \%$ of the variance in sexual identity $\left(R^{2}=.181, F(8,239)=6.378\right.$, $p<.001)$. It was found that popular, rejected, open family communication, and intrinsic religious orientation significantly predicted sexual identity among adolescent girls. Open family communication $(\beta=.207, p=.008)$ and intrinsic religious orientation $(\beta=.163, p=.024)$ were the most powerful predictors of sexual identity in adolescent girls. The implications of this study can be used for schools and parents and will be discussed in this article.
\end{abstract}

Keywords: sexual identity; peer acceptance; parent-adolescent communication; religious orientation

\section{Introduction}

Adolescent girls encounter various challenges in the formation of sexual identity. Shively (1977) mentioned that sexual identity was a self-evaluation process of a set of individual characteristics which were related to appearance, behavior, and personality perceived as masculine and feminine stereotypes. Generally, adolescent girls consider themselves as feminine (Stern, Barak, \& Gould, 1987).

Adolescent girls can experience challenges in sexual identity formation, in which it would be used later in their adulthood. During adulthood, one of women's role is to be a mother. As a mother, the woman is responsible for coordinating various family responsibilities which include child-rearing and household maintenance. Those responsibilities require feminine qualities (Arrindell et al., 2003; Hurlock, 1980; Mahalik, 2005)

There are several factors that influence the formation of sexual identity. These include peer acceptance, parent communication, and religious orientation (Worthington, Savoy, Dillon, \& Venaglia, 2002).
Peer acceptance is the degree to which an individual is socially accepted by her or his peers (Slaughter, Dennis, \& Pritchard, 2002). Peers become significant in adolescence as the frequency of meeting with them is more dominant than with family in their daily activities (Bahar, 1982). It was confirmed by Golshirazian, Dhillon, Maltz, Payne, and Rabow'study (2015) that peer groups give significant impact to sexual identity. Moreover, at this time individuals are required to adjust socially to gain acceptance from others, where acceptance is used to establish relationships (Hurlock, 1980).

Parent-adolescent communication is the act of exchanging information, ideas, thoughts, and feeling between parent and adolescent (Olson \& Barnes, 2017). During adolescence, parental communication is important to understand sexual identity formation (Block, 1973, in Werrbach, Grotevant, \& Cooper, 1992). Werrbach et al. (1990, in Werrbach et al., 1992) stated that adolescent girls who have a lower feminine sexual identity indicated that they spent less time with their parents.

Religious orientation is a view of the position of religion that affects the behavior of individuals in 
their lives (Allport \& Ross, 1967, in McCormick, Hoekman, \& Smith, 2000). Religion and sexuality are closely related because every religion regulates sexual aspects among its memberships (Parrinder, 1987, in Worthington et al., 2002).

The present study aims to examine the role of peer acceptance, parent communication, religious orientation, and sexual identity in adolescent girls.

\section{Methods}

Sample. This study used simple random sampling technique. Sample framing was data of High School in Jakarta from The Ministry of Education and Culture. In each school, participants were selected using accidental sampling technique. There were 240 participants selected based on the following criteria: a) schoolgirl between 14-17 years old; b) having no physical or mental disorders, and c) provide informed consent. Table 1 shows the participants' characteristic.

\section{Instrument and Measurement.}

Sexual Identity. Sexual identity was assessed using the De Cecco-Shively Social Sex-Role Inventory (DSI) by Shively, Rudolph, and Cecco (1978). It consists of 25 items to measure appearance, interest, mannerism, and personality dimensions. The items are scored on a 4-point Likert scale, with possible responses ranging from 1 (very inappropriate) to 4 (very appropriate).

Peer Acceptance. Peer acceptance was assessed using the Peer Acceptance Scale by Newcomb, Bukowski, and Patte (1993). The instrument was modified and adapted. It consists of 20 items to measure popular, rejected, neglected, and controversial dimensions. The items scored on a 4point Likert scale, with possible responses ranging from 1 (very inappropriate) to 4 (very appropriate).

Parent-Adolescent Communication. Parentadolescent communication was assessed using The Communication Parent-Adolescent Communication Scale by Barnes and Olson (1985). This scale was modified and adapted. It consists of 20 items to measure open family communication and problemfree in family communication. The items scored on a 4-point Likert scale, with possible responses ranging from 1 (very inappropriate) to 4 (very appropriate).

Religious Orientation. Religious orientation was assessed using the Age-Universal Scale by Gorsuch and Venable (1983). This scale was modified and adapted. It consists of 20 items to measure intrinsic and extrinsic. The items scored on a 4-point Likert

scale, with possible responses ranging from 1 (very inappropriate) to 4 (very appropriate).

Procedure. The questionnaires were administered in a class. First, participants were assisted to sign the informed consent and were read the instruction. Then, they completed the questionnaires. Twohundred and forty questionnaires were administered and returned with completed answers.

\section{Results}

Table 1.

Sample Characteristics $(n=240)$

\begin{tabular}{lc}
\hline \multicolumn{1}{c}{ Characteristics } & n (\%) \\
\hline Grade & \\
First grade & $120(50)$ \\
Second grade & $120(50)$ \\
Age (years) & \\
14-15 years old & $71(30)$ \\
16-17 years old & $169(70)$ \\
Religion & \\
Hindu & $1(1)$ \\
Islam & $212(88)$ \\
Catholic & $3(1)$ \\
Christian & $8(3)$ \\
Protestant & $16(7)$ \\
Living with parent & \\
Yes & $238(99)$ \\
No & $2(1)$ \\
\hline
\end{tabular}

The findings are presented in Table 2 and show that $18.1 \%$ variance of sexual identity was predicted by peer acceptance (popular, rejected, neglected, controversial), parent communication (open family communication, problem-free in family communication), and religious orientation (intrinsic, extrinsic) $\left(R^{2}=.181, F=8,239=6.378, p<.001\right)$.

Table 2.

Multiple Regression

\begin{tabular}{|c|c|c|c|c|c|}
\hline \multirow[t]{2}{*}{ Predictor } & \multicolumn{2}{|c|}{$\begin{array}{l}\text { Unstd } \\
\text { Coeff }\end{array}$} & \multirow{2}{*}{$\begin{array}{c}\begin{array}{c}\text { Stan } \\
\text { d } \\
\text { Coeff }\end{array} \\
\text { B }\end{array}$} & \multirow[t]{2}{*}{$\mathbf{t}$} & \multirow[t]{2}{*}{ Sig. } \\
\hline & B & S.E & & & \\
\hline \multirow{2}{*}{$\begin{array}{l}\text { Popular } \\
\text { Rejected }\end{array}$} & .178 & .085 & .172 & 2.083 & $.038^{*}$ \\
\hline & -.158 & .080 & -.130 & 1.966 & $.050^{*}$ \\
\hline Neglected & -.064 & .083 & -.063 & -.773 & .440 \\
\hline Controv & .044 & .080 & .037 & .546 & .585 \\
\hline Open FC & .195 & .074 & .207 & 2.654 & $.008^{*}$ \\
\hline $\begin{array}{l}\text { Problem-free } \\
\text { FC }\end{array}$ & -.066 & .085 & -.064 & -.780 & .436 \\
\hline Intrinsic & .156 & .069 & .163 & 2.268 & $.024^{*}$ \\
\hline Extrinsic & .114 & .063 & .112 & 1.793 & .074 \\
\hline
\end{tabular}


Result showed that popular $(\beta=.172, p=.038)$ and rejected $(\beta=-.130, p=.050)$ in peer acceptance, open family communication $(\beta=.207, \quad p=.008)$, and religious intrinsic $(\beta=.163, p=.024)$ were significant individual predictors of sexual identity among adolescent girls.

\section{Discussion \& Conclusion}

The current study shows that peer acceptance, parent communication, religious orientation are significant predictors of sexual identity among adolescent girls. The result showed that there are positive and negative influences to predict sexual identity. Positive influence means that the higher the value of a dimension in adolescent girls, the perception of feminine sexual identity will also be higher. Conversely, negative influence means that the higher the value of a dimension in adolescent girls, the perception of feminine sexual identity will be lower.

Popular peer acceptance has a significant positive influence on sexual identity in adolescent girls. Popular individuals are individuals who have high intellectual and good social skills, so they receive high peer acceptance as well (Newcomb et al., 1993). Kreiger and Kochendefer (2013) explained that these individuals tend to do activities and have the appropriate options that match their gender, feminine sexual identity.

The current study found that rejected by peer has a negative effect on sexual identity of adolescent girls. The previous study (Newcomb et al., 1993) showed that rejection was characterized by being less socializing and aggressive toward friends. Those characteristics belonged to lower feminine sexual identity as in Kreiger and Kochendefer-Ladd's research (2013). Messerschmidt (1993, in Omar, 2011) found that aggressive individuals wanted to show their unfemininity.

Family communication had a significant positive influence on sexual identity in adolescent girls. Werrbach et al. (1990, in Werrbach et al., 1992) stated that adolescents who frequently spent time with their parents improved the understanding of their role in the future. They also can distinguish and understand the sexual identity that they should choose (Block, 1973, 1978, in Werrbach et al., 1992). Horan, Houser, and Cowan (2007) found that appropriate sexual identity is a sign that an individual receives messages about it from their parents. Marks et al. (2009) also found that the appropriate sexual identity was due to the amount of conflict and quality of relationship with parents.
Religious intrinsic orientation had a significant positive influence on sexual identity in adolescent girls. Skegg (1997, in Siraj, 2012) found that religious adolescent girls choose and use feminine sexual identity. The intrinsic individuals use religion as their main needs so they are religious people (Allport \& Ross, 1967). Reich (1997, in Rich, 2012) stated that individuals who strongly believed in their religion tended to be unaffected both norm and socio-cultural, including the introduction of masculine sexual identity in women.

This study has some limitations. First, because the participants were only adolescent girls, it is suggested that future study should consider to measure feminine sexual identity in adolescent boys and develop this measurement to both genders. The participants in this study were from urban area, thus it is suggested those from rural area be included in further studies.

The study emphasizes the importance of the role of peer, family, and religious orientation on sexual identity among adolescent girls. Based on this study, it is important to develop school-based education on sexual identity development for adolescent girls and their parents.

\section{References}

Ali, T. S., Krantz, G. M., Gul, R., Asad, R., Johansson, E., Mogren, I. (2011). Gender Role and Their Influence of Life Prospects for Women in Urban Karachi, Pakistan: a Qualitative Study. Glob Health Action, 4. DOI: 10.3402/gha.v4i0.7748.

Allport, G. W., \& Ross, J. M. (1967). Personal Religious Orientation and Prejudice. Journal of Personality and Social Psychology, 5.(4), 432-443.

Arrindell, W. A., Eisemann, M., Ritcher, J., Oei, T. P. S., Caballo, V. E., Ende, J. V. D., Sanavio, E., Bages, N., Feldman, L., Torres, B., Sica, C. Iwawaki, S., \& Hatzichristou, C. (2003). Masculinity-femininity as National Characteristic and Its Relationship with National Geographic fear levels: Fodor's: Sex Role Hypothesis Revitalized. Behavior Research and Therapy, 41, 795-807.

Bahar, M. (1977). Peranan Keluarga dan Kelompok Teman Sebaya dalam Pembentukkan Pola Tingkah Laku Remaja. Thesis: Indonesia University.

Barnes, H. L., \& Olson, D. H. (1985). Parent-Adolescent Communication and the Circumplex Model. Child Development, 56 (2), 438-447.

Darvyri, P., Galanakis, M., Avgoustidis, A. G., Pateraki, N., Vasdekis, S., \& Darviri, C. (2014). The Revised Intrinsic/Extrinsic Religious Orientation Scale in a Sample of Attica's Inhabitants. Psychology, 5, 1557-1567.

Golshirazian, S., Dhillon, M., Maltz, S., Payne, K. E., \& Rabow, J. (2015). The Effect of Peer Group on Gender Identity and Expression. International Journal of Research in Humanities and Social Studies, 2 (10), 9-17

Gorsuch, R. L., \& Venable, G. D. (1983). Development of an Age Universal I-E Scale. Journal for the Scientific Study of Religion, 22, 181-187. 
Hurlock, E. B. (1980). Psikologi Perkembangan: Suatu Pendekatan Sepanjang Rentang Kehidupan. Erlangga: Jakarta.

Horan, S. M., Houser, M. L., \& Cowan, R. L. (2007). Are Children Communicated with Equally? An Investigation of Parent-Child Sex Composition and Gender Role Communication Differences. Communication Research Reports, 24 (4), 361-372.

Kemdikbud. (2015). Data Pokok Sekolah Menengah Atas (SMA). Accessed in $21^{\text {st }}$ July 2016 from http://www.psma.kemdikbud.go.id.

Kreiger, T. C., \& Ladd, K. B. (2013). Gender Behaviors as Predictors of Peer Acceptance and Victimization. Personal Relationship, 20, 619-634.

Mahalik, J. R., Morray, E. B., Femiano, A. C., Ludlow, L. H., Slattery, S. M., \& Smiller, A. (2005). Development of the Conformity to Feminine Norms Inventory. Sex Roles, 52 (7/8), 417-435.

Marks, J., Bun, L. C., \& McHale, S. M. (2009). Family Patterns of Gender Role Attitudes. Sex Roles, 61 (3-4), 221-234.

Martin, J. N., \& Nakaya,a, T. K. (2010). Intercultural Communication in Context. McGraw-Hill: New York.

McCormick, J., Hoekman C., \& Smith, D. (2000). Religious Orientation \& Locus of Control in an Australian Open Enrolment Christian School. Australian Association for Research in Education. Publikasi online. WEB: http://www.aare.edu.au/00pap/mcc00072.htm

Newcomb, A. F., Bukowski, W. M., \& Pattee, L. (1993). Children Peer Relations: A Meta-Analytic Review of Popular, Rejected, Neglected, Controversial, and Average Sociometric Status. Psychological Bulletin, 113 (1), 99128.

Olson, D. H., \& Barnes, H. (2017). Family Communication. Life Innovations. WEB: www.facesiv.com.
Omar, A. R. (2011). Masculinity and The Acceptance of Violence: A Study of Social Construction. Iowa Research Online: University of Iowa.

Rich, A. (2012). Gender and Spirituality: Are Women Really More Spiritual?. Thesis: Liberty University.

Rowland, D. L., \& Inrocci, L. (2008). Handbook of Sexual and Gender Identity Disorder. Wiley: New Jersey.

Santrock, J. W. (2007). Remaja Edisi 11 Jilid 2. Erlangga: Jakarta.

Shively, M. G. (1977). Component of Sexual Identity. Journal of Homosexuality, 3 (1), 41-48.

Shively, M. G., Rudolph, J. R., \& Cecco, J. P. D. (1978). The Identification of the People Sex-Role Stereotypes. Journal of Homosexuality, 3 (3), 225-234.

Siraj, A. (2012). 'Smoothing Down Ruffled Feathers': The Construction of Muslim Women's Feminine Identities. Journal of Gender Studies, 21 (2), 185-199.

Slaughter, V., Dennis, M. J., \& Pritchard. (2002). Theory of Mind and Peer Acceptance in Preschool Children. British Journal of Developmental Psychology, (20), 545-564.

Stern, B. B., Barak, B., \& Gould, S. J. (1987). Sexual Identity Scale: A New Self-Assessment Measure. Sex Roles, 17 (9/10), 503-519.

Werrbach, G. B., Grotevant, H. D., \& Cooper, C. R. (1992). Patterns of Family Interaction and Adolescent Sex Role Concepts. Journal of Youth and Adolescence, 21 (5), 609623.

Worthington, R. L., Savoy, H. B., Dillon, F. R., \& Venaglia, E. R. (2002). Heterosexual Identity Development: a Multidimensional Model of Individual and Social Identity. Journal Counseling Psychologist, 30, 496-531.

Wulff, D. M. (1991). Psychology of Religion: Classic and Contemporary Views. Wiley: New York. 